\title{
CRLF1 wt Allele
}

National Cancer Institute

\section{Source}

National Cancer Institute. CRLF1 wt Allele. NCI Thesaurus. Code C104951.

Human CRLF1 wild-type allele is located in the vicinity of $19 \mathrm{p} 12$ and is approximately $14 \mathrm{~kb}$ in length. This allele, which encodes cytokine receptor-like factor 1 protein, may play roles in nervous system development and immune function. Mutations in this gene are associated with cold-induced sweating syndrome and Crisponi syndrome. 